DOI: $10.31933 / \mathrm{JIMT}$

Received: 11 Juli 2020, Revised: 25 Agustus 2020, Publish: 21 September 2020

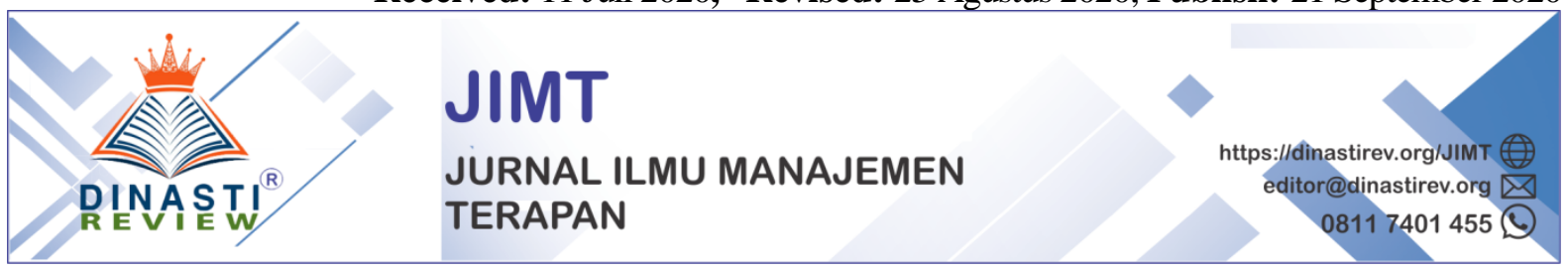

\title{
PENGARUH KEPUASAN KERJA, KOMITMEN ORGANISASIONAL, DAN JOB INSECURITY TERHADAP ORGANIZATIONAL CITIZENSHIP BEHAVIOUR (OCB) (STUDI PADA PEGAWAI NON-PNS KEMENTERIAN SOSIAL RI)
}

\author{
Dhisa Tania Priyadi ${ }^{1}$, Mahendro Sumardjo², Santosa Iman Mulyono ${ }^{3}$ \\ 1) Universitas Pembangunan Nasional Veteran Jakarta, Indonesia, dhisatp@yahoo.com \\ 2) Universitas Pembangunan Nasional Veteran Jakarta, Indonesia \\ 3) Universitas Pembangunan Nasional Veteran Jakarta, Indonesia
}

\section{Corresponding Author: First Author}

\begin{abstract}
Abstrak: Penelitian ini merupakan penelitian kuantitatif yang bertujuan untuk mengetahui bagaimana pengaruh kepuasan kerja, komitmen organisasional, dan job insecurity terhadap Organizational Citizenship Behaviour (OCB). Populasi dalam penelitian ini adalah pegawai honorer Direktorat Jenderal Perlindungan dan Jaminan Sosial, Kementerian Sosial Republik Indonesia. Sampel yang digunakan sebesar 75 responden dengan menggunakan teknik probability sampling, khususnya simple random sampling. Teknik pengumpulan data dalam penelitian ini ialah dengan menggunakan kuesioner. Teknik analisis data yang digunakan ialah metode analisis Partial Least Square (PLS). Hasil penelitian menunjukkan bahwa: 1) Kepuasan Kerja berpengaruh signifikan terhadap Organizational Citizenship Behavior (OCB) dengan nilai koefisien jalur sebesar 0.259 ; 2) Komitmen Organisasional berpengaruh signifikan terhadap Organizational Citizenship Behavior (OCB) dengan nilai koefisien jalur sebesar 0.777; dan 3) Job Insecurity menunjukkan pengaruh yang tidak signifikan dan memiliki hubungan negatif terhadap Organizational Citizenship Behavior (OCB) dengan nilai koefisien jalur sebesar -0.071 .
\end{abstract}

Kata Kunci: Kepuasan Kerja, Komitmen Organisasional, Job Insecurity, Organizational Citizenship Behaviour (OCB)

\section{PENDAHULUAN}

Indonesia secara geografis adalah negara kepulauan yang terletak pada pertemuan empat lempeng tektonik yaitu lempeng Benua Asia, Benua Australia, lempeng Samudera Hindia dan Samudera Pasifik. Bagian selatan dan timur Indonesia terdapat sabuk vulkanik (volcanic arc) yang memanjang dari Pulau Sumatera, Jawa - Nusa Tenggara, Sulawesi, yang sisinya berupa pegunungan vulkanik tua dan dataran rendah yang sebagian didominasi oleh rawa-rawa. Kondisi tersebut sangat berpotensi sekaligus rawan bencana seperti gempa bumi, banjir, tsunami, tanah longsor, hingga letusan gunung berapi. Indonesia merupakan salah satu negara yang memiliki tingkat kegempaan tinggi di dunia, lebih dari 10 kali lipat dari tingkat kegempaan di Amerika Serikat (Arnold dalam bnpb.go.id). 
Kementerian Sosial Republik Indonesia (Kemensos RI) adalah kementerian yang memiliki tugas untuk membantu presiden dalam penyelenggaraan pemerintahan negara di bidang sosial. Salah satu tugas yang dimiliki Kemensos RI adalah memberikan bantuan kepada korban bencana alam maupun bencana sosial. Rencana stratejik telah ditetapkan Kemensos RI pada tahun 2019 dalam hal penanggulangan bencana. Tercapainya sasaran organisasi dapat dicapai jika Sumber Daya Manusia (Human Capital Resource) didalamnya mau melakukan tugas ekstra diluar job description nya. Kinerja individu secara kolektif inilah yang akan menentukan kinerja organisasi secara keseluruhan untuk mencapai tujuan. Kinerja organisasi bergantung pada sebuah peran ekstra, peran ekstra ini tidak dapat diwajibkan atau diharuskan untuk suatu pekerjaan tertentu. Perilaku ini merupakan suatu perilaku yang tidak mewajibkan pegawai untuk melakukan peran ini, karena peran ini secara tidak langsung berada didalam pekerjaan yang sebenarnya. Sebagai contoh adalah membantu rekan kerja yang sedang mengalami masalah atau kesulitan. Perilaku tersebut dikenal sebagai citizenship behavior (Bateman \& Organ, 1983).

Organizational Citizenship Behavior (OCB) atau perilaku kewargaan organisasi diperkenalkan sebagai perilaku pegawai yang melebihi peran yang diwajibkan, yang tidak secara langsung diakui oleh sistem penghargaan (reward) formal, merupakan perilaku pilihan yang tidak menjadi bagian dari kewajiban formal seorang pegawai, namun mendukung berfungsinya organisasi tersebut secara efektif (Organ dalam Lubis, 2015). Artinya, OCB secara sederhana dapat dikatakan sebagai perilaku individu yang berakar pada kesediaannya untuk berkontribusi melebihi peran inti atau tugasnya terhadap organisasinya. Pegawai yang melakukan perilaku OCB tidak selalu mendapatkan reward dari perusahaan, karena perilaku ini tidak wajib dilakukan dan tidak ada sanksi dari perusahaan jika seorang pegawai tidak melakukan perilaku OCB.

Ada beberapa faktor pendorong bagi pegawai sehingga dapat menunjukkan perilaku OCB. Salah satu faktor yang dapat mendorong munculnya OCB di organisasi adalah kepuasan kerja. Robbins \& Judge (2013:40) mengemukakan bahwa kepuasan kerja yaitu suatu perasaan positif tentang pekerjaan seseorang yang merupakan hasil dari evaluasi karakteristiknya. Kepuasan kerja menjadi penting dalam sebuah organisasi karena kepuasan kerja memberikan dampak positif terhadap efektifitas organisasi. Pegawai yang puas cenderung berbicara positif tentang organisasi, membantu individu lain, dan melebihi harapan normal dalam pekerjaan mereka. Pegawai yang puas mungkin lebih patuh pada panggilan tugas karena ingin mengulang pengalaman-pengalaman positif yang pernah dirasakan. Kepuasan kerja yang dirasakan pegawai dapat memberikan dampak yang besar bagi individu yang bersangkutan maupun bagi organisasi di tempat individu tersebut berada. Selain dapat mendorong munculnya OCB, kepuasan kerja adalah salah satu alasan meningkatnya komitmen organisasi. Individu yang merasa puas akan pekerjaannya akan memiliki komitmen terhadap organisasi dan begitu pula sebaliknya (Shah et al., 2012).

Budiharjo (2004) menyatakan bahwa komitmen organisasional secara signifikan berkorelasi dengan OCB. Pegawai yang memiliki komitmen tinggi akan lebih berorientasi pada pekerjaan, akan cenderung membantu dan dapat bekerjasama, yang merupakan bagian dari sikap OCB. Komitmen organisasi adalah sikap yang mencerminkan sejauh mana seorang individu mengenal dan terikat pada organisasinya. Komitmen organisasi dibangun melalui 
suatu proses identifikasi dimana seseorang melakukan sesuatu dari suatu ide sebagai pengembangan dirinya. Memiliki tenaga kerja yang memiliki komitmen akan menambah keunggulan suatu organisasi (Meyer \& Allen dalam Brahmasari, 2008).

Satu sisi, terdapat pengaruh negatif job insecurity terhadap organizational citizenship behaviour. Job insecurity mengacu pada "rasa ketidakberdayaan pegawai untuk mempertahankan kontinuitas karena terancam oleh situasi dalam pekerjaan". De Witte (2005) menyebutkan bahwa job insecurity sebagai "the threat of unemployment" atau suatu tekanan yang berasal dari status pegawai yang bukan merupakan pegawai tetap. Hasil ini menjelaskan keterkaitan job insecurity sebagai pemicu stress yang tidak dapat terhindari, karena pegawai merasa tidak memiliki kesempatan untuk berkembang secara professional. Sebagai suatu gangguan kerja, job insecurity akan menghambat pencapaian tujuan kerja dan akan mengurangi perilaku positif pada individu dan organisasi (Stynen et al., 2015).

Instansi publik merupakan salah satu sarana yang dimiliki oleh negara untuk melayani kebutuhan masyarakat. Instansi publik tersebar untuk melayani di bidang kesehatan, pendidikan, keamanan, hokum dan masih banyak bidang lainnya. Sebagai agen untuk melayani kebutuhan masyarakat, instansi publik diharapkan sekaligus dituntut untuk memiliki produktifitas kerja yang baik dalam melayani masyarakat. Darto (2014) berpendapat bahwa di era reformasi birokrasi sebagaimana saat ini sedang dijalankan di berbagai instansi pemerintahan, peran OCB dianggap vital dan sangat menentukan kinerja organisasi. Selain sebagai unsur yang unik dari perilaku dalam dunia kerja, OCB juga merupakan aspek yang hampir tidak biasa dalam lingkup aparatur pemerintahan.

Realitanya, perilaku OCB pegawai sulit dan jarang ditemui pada instansi publik. Walaupun dirasakan masih langka dan jarang ditemui, tetapi munculnya OCB merupakan hal positif bagi instansi publik termasuk Kementerian Sosial Republik Indonesia. Berdasarkan pra riset yang dilakukan oleh peneliti di Kemensos RI masih ditemukan masalah yaitu jam 09.00 sd 12.00 intensitas kerja tinggi, namun setelah itu intensitas kerja mulai berkurang. Kerja yang efektif adalah jika target kerja sudah selesai pada hari itu. Pegawai harus mencurahkan tenaga dan pikiran untuk segera melakukan hal-hal lain yang menjadi target berikutnya. Dalam hal ini, jika pegawai belum selesai mengerjakan target kerja mereka masing-masing, pegawai menjadi tidak bisa membantu rekan kerjanya.

\section{KAJIAN PUSTAKA \\ Kepuasan Kerja}

Kepuasan kerja adalah merupakan hal yang bersifat individual karena setiap individu akan memiliki tingkat kepuasan yang berbeda sesuai dengan nilai-nilai yang berlaku pada masing-masing individu. Semakin banyak aspek pekerjaan yang sesuai dengan keinginan individu, semakin tinggi tingkat kepuasan yang dirasakan. Kepuasan kerja menurut Robbins \& Judge (2013:40) adalah suatu perasaan positif tentang pekerjaan seseorang yang merupakan hasil dari evaluasi karakteristiknya. Keyakinan bahwa karyawan yang merasa puas jauh lebih produktif bila dibandingkan dengan karyawan yang tidak puas telah menjadi prinsip dasar diantara para manajer selama bertahun-tahun.

Ivancevich et al. (2011:90) mengemukakan kepuasan kerja adalah sikap seseorang terhadap pekerjaan mereka. Hal tersebut dihasilkan dari persepsi mereka tentang pekerjaan mereka dan tingkat kesesuaian antara individu dengan organisasi. Michell \& Larson (dalam Sinambela, 2016: 302) mengemukakan setidaknya terdapat dua alasan untuk mengetahui 
kepuasan dan akibatnya yaitu, kepuasan bersumber dari faktor organisasi. Kepuasan adalah suatu hal yang dapat memengaruhi perilaku kerja, kelambanan bekerja, ketidakhadiran, dan keluar masuknya pegawai. Kepuasan juga bersumber dari sumber daya dan penyebab kepuasan. Karena kepuasan sangat penting untuk meningkatkan kinerja perorangan.

\section{Komitmen Organisasional}

Komitmen organisasi merupakan dimensi perilaku penting yang dapat digunakan untuk menilai kecenderungan karyawan untuk bertahan sebagai anggota organisasi. Komitmen Organisasi menurut Robbins \& Judge (2013:100) adalah tingkat sampai mana seorang karyawan memihak sebuah organisasi serta tujuan-tujuan dan keinginannya untuk mempertahankan keanggotaan dalam organisasi tersebut. Kreitner \& Kinicki (2014:165) mendefinisikan komitmen organisasi yaitu tingkatan dimana seseorang mengenali sebuah organisasi dan terikat pada tujuan-tujuannya. Ini adalah sikap kerja yang penting karena orangorang yang memiliki komitmen diharapkan bisa menunjukkan kesediaan untuk bekerja lebih keras demi mencapai tujuan organisasi dan memiliki hasrat yang lebih besar untuk tetap bekerja di suatu perusahaan.

Menurut Noe, Hollenbeck, Gerhart, dan Wright (2014:308) komitmen organisasi adalah sejauh mana seorang karyawan mengidentifikasi organisasi dan bersedia untuk mengajukan upaya atas namanya. Karyawan dengan komitmen organisasi yang tinggi akan meregangkan diri mereka untuk membantu organisasi melalui masa-masa sulit. Karyawan dengan komitmen organisasi rendah cenderung meninggalkan pada kesempatan pertama untuk pekerjaan yang lebih baik. Mereka memiliki niat kuat untuk pergi, jadi seperti karyawan dengan keterlibatan kerja yang rendah, mereka sulit untuk memotivasi. Sedangkan, menurut Hellriegel \& Slocum (2011:91), komitmen organisasi adalah kekuatan keterlibatan karyawan dalam organisasi. Karyawan yang tinggal dengan organisasi mereka untuk jangka waktu yang panjang cenderung lebih berkomitmen untuk organisasi daripada mereka yang bekerja untuk jangka waktu yang lebih singkat.

David (dalam Sopiah, 2011:163) mengemukakan empat faktor yang memengaruhi komitmen pegawai terhadap organisasi, yaitu:

1. Faktor personal, misalnya: usia, jenis kelamin, tingkat pendidikan, pengalaman kerja, dan kepribadian.

2. Karakteristik pekerjaan, misalnya: ruang lingkup jabatan, tantangan dalam pekerjaan, konflik peran dalam pekerjaan, dan tingkat kesulitan dalam pekerjaan.

3. Karakteristik struktur, misalnya: ukuran organisasi, bentuk organisasi seperti sentralisasi atau desentralisasi, keberadaan serikat pekerja, dan tingkat pengendalian yang dilakukan oleh organisasi terhadap pegawai.

4. Pengalaman kerja.

Komitmen karyawan terhadap organisasi adalah bertingkat, dari tingkatan yang sangat rendah hingga tingkatan yang sangat tinggi. Ditinjau dari segi organisasi, menurut Steer (dalam Sopiah, 2011:166) karyawan yang berkomitmen rendah akan berdampak pada turn over, tingginya absensi, meningkatnya kelambatan kerja dan kurangnya intensitas untuk bertahan sebagai karyawan di organisasi tersebut, rendahnya kualitas kerja, dan kurangnya loyalitas pada perusahaan. Karyawan yang memiliki komitmen organisasional yang tinggi dampaknya adalah tingkat stress berkurang. Sedangkan, karyawan yang memiliki komitmen organisasional yang tinggi akan berdampak pada karyawan tersebut yaitu karyawan lebih puas dengan pekerjaannya dan tingkat absensinya menurun.

\section{Job Insecurity}


Job insecurity merupakan rasa tidak aman dalam bekerja yaitu ancaman untuk tidak lagi menjadi pegawai tetap pada perusahaan yang sama. Menurut Greenhalgh \& Rosenblatt (1984) job insecurity adalah ketidakberdayaan untuk mempertahankan kelanjutan pekerjaan karena ancaman situasi dari suatu pekerjaan. Smithson \& Lewis (2000) mengartikan job insecurity sebagai kondisi psikologis seseorang yang menunjukkan rasa bingung atau merasa tidak aman dikarenakan kondisi lingkungan yang berubah-ubah (perceived impermanance). Kondisi ini muncul karena banyaknya jenis pekerjaan yang sifatnya sesaat atau pekerjaan kontrak. Makin banyaknya jenis pekerjaan dengan durasi waktu yang sementara atau tidak permanen menyebabkan semakin banyaknya karyawan yang mengalami job insecurity. Greenglass et al. (2002) menjelaskan job insecurity sebagai kondisi yang berhubungan dengan rasa takut seseorang akan kehilangan pekerjaannya atau prospek akan demosi atau penurunan jabatan serta berbagai ancaman lainnya terhadap kondisi kerja yang berasosiasi dengan menurunnya job satisfaction.

Job insecurity timbul berdasarkan persepsi dan interpretasi individu terhadap lingkungan kerja saat ini. Hal ini menunjukkan bahwa pengalaman subjektif individu muncul sebagai akibat dari ancaman nyata yang dihadapinya di lingkungan kerja melalui proses persepsi kognitif. Job insecurity difokuskan untuk mengantisipasi kemungkinan kejadian di masa depan, yaitu kehilangan pekerjaan. Fokus masa depan dari job insecurity menunjukkan bahwa job insecurity dihadapkan dengan mempertimbangkan konsekuensi yang akan membawa kehilangan pekerjaan, seperti beban keuangan. Job insecurity juga melibatkan risiko kehilangan pekerjaan atau kehilangan komponen pekerjaan yang berharga. Kerugian mungkin hanya bersifat finansial, atau bisa juga non-fisik, seperti hilangnya status yang disediakan oleh pekerjaan.

Job insecurity tidak hanya berdampak pada diri pegawai saja, tetapi juga terhadap organisasi atau perusahaan tempat tenaga kerja bekerja. Berikut ini adalah dampak yang timbul dari job insecurity (Greenhalgh \& Rosenblatt, 1984):

1. Stress

Job insecurity dapat menyebabkan ketakutan, kehilangan kemampuan, dan kecemasan. Pada akhirnya, jika ini dibiarkan berlangsung untuk waktu yang lama, pegawai dapat menjadi stress karena adanya rasa tidak aman dan ketidakpastian akan kelangsungan pekerjaan.

2. Job satisfaction

Job insecurity memengaruhi job satisfaction. Pegawai yang merasa dirinya tidak aman tentang kelangsungan pekerjaan mereka cenderung merasa tidak puas dibandingkan mereka yang merasakan kepastian masa depan pekerjaan mereka.

3. Komitmen dan kepercayaan pegawai terhadap perusahaan.

Job insecurity memiliki hubungan negatif dengan komitmen kerja dan kepercayaan pegawai terhadap perusahaan. Hal ini disebabkan karena pegawai merasa akan kehilangan kepercayaan pada nasib mereka di perusahaan dan lama kelamaan ikatan antara pegawai dan organisasi menghilang.

4. Motivasi kerja

\section{Organizational Citizenship Behavior (OCB)}

Peran perilaku yang dibutuhkan dari seorang pegawai meliputi in role dan extra role. In role adalah peran yang diminta oleh organisasi dari seorang pegawai sesuai dengan uraian pekerjaan dan sesuai dengan imbalannya. Extra role adalah peran yang diharapkan oleh perusahaan dari seorang pegawai yang tidak terkait dengan deskripsi pekerjaan atau melebihi apa yang seharusnya. Hal ini sangat diperlukan untuk mencapai efektivitas dan keberhasilan suatu organisasi. Kontribusi pekerja di atas dan lebih dari deskripsi pekerjaan formal adalah 
apa yang disebut Organizational Citizenship Behavior (OCB) (Organ et al., 1989). Konsep perilaku organizational citizenship behavior pertama kali dibahas dalam literatur penelitian organisasi pada awal 1980-an.

Organ et al. (1989) mendefinisikan organizational citizenship behavior sebagai perilaku individu yang mempunyai kebebasan untuk memilih, yang secara tidak langsung atau tidak secara eksplisit dikaitkan dengan sistem reward, dan memberi kontribusi pada efektivitas dan efisiensi fungsi organisasi. Djati (dalam Titisari, 2014:6) mengemukakan organizational citizenship behavior adalah perilaku karyawan yang tidak nampak baik terhadap rekan kerja maupun terhadap perusahaan, dimana perilaku tersebut melebihi dari perilaku standar yang ditetapkan perusahaan dan memberikan manfaat bagi perusahaan. Dengan demikian dapat disimpulkan bahwa organizational citizenship behavior adalah perilaku yang bersifat suka rela dan dipilih sendiri oleh karyawan yang memberikan kontribusi dalam meningkatkan efektivitas dan efisiensi organisasi dan tidak terkait dengan sistem reward.

Fokus dari konsep ini adalah mengidentifikasi perilaku pegawai yang diukur dengan menggunakan alat ukur kinerja pegawai yang tradisional. Elemen dalam konsep organizational citizenship behavior menurut Stamper \& Dyne (dalam Titisari, 2014:6) yaitu:

1. Organizational Citizenship Behavior $(O C B)$ adalah jenis perilaku di mana pegawai menunjukkan perilaku yang melebihi permintaan perusahaan.

2. Organizational Citizenship Behavior $(O C B)$ merupakan perilaku yang tidak terlihat.

3. Perilaku pegawai ini tidak secara langsung mendapat penghargaan atau mudah dikenali oleh struktur perusahaan formal.

4. Organizational Citizenship Behavior (OCB) adalah perilaku penting untuk meningkatkan efektivitas perusahaan.

Menurut McClelland et al. (dalam Titisari, 2014:9), manusia memiliki tiga tingkatan motif, yaitu:

1. Motif berprestasi, mendorong orang untuk menunjukkan standar keunggulan (excellence), mencari prestasi dari tugas, kesempatan, atau kompetisi.

2. Motif afiliasi, mendorong orang untuk mewujudkan, memelihara dan memengaruhi, serta meningkatkan hubungan dengan orang lain.

3. Motif kekuasaan, mendorong orang untuk mencari status dan kontrol dimana mereka dapat mengontrol pekerjaan atau tindakan orang lain.

\section{Pengaruh Kepuasan Kerja terhadap Organizational Citizenship Behavior (OCB)}

Kepuasan kerja pegawai dapat ditingkatkan dengan menyediakan hal-hal penting bagi pegawai, seperti membuka peluang promosi yang baik, memberikan pengawasan yang efektif, menciptakan harmoni di antara rekan kerja, sehingga pegawai akan merasa puas dengan pekerjaan mereka dan akan meningkatkan perilaku $O C B$. Ketika pegawai merasakan kepuasan dengan pekerjaan yang mereka lakukan, maka pegawai tersebut akan bekerja secara optimal dalam menyelesaikan pekerjaan mereka, bahkan melakukan beberapa hal yang mungkin berada di luar tugas mereka (Luthans, 2012:146).

Kepuasan kerja adalah penentu penting yang mendorong seseorang untuk menunjukkan perilaku Organizational Citizenship Behavior (OCB), karena individu yang mendapatkan kepuasan dalam pekerjaannya akan cenderung menafsirkan pekerjaan dan tugas yang mereka lakukan dengan tanggung jawab dan penuh dedikasi. Temuan penelitian sebelumnya yang dilakukan oleh Sudarmo \& Wibowo (2018) meneliti hubungan antara kepuasan kerja dan $O C B$, mereka menemukan bahwa setiap dimensi kepuasan kerja berkorelasi positif dengan Organizational Citizenship Behavior (OCB). 
H1: Kepuasan kerja berpengaruh positif dan signifikan terhadap Organizational Citizenship Behavior $(O C B)$ pada pegawai non-PNS di Kementerian Sosial Republik Indonesia.

\section{Pengaruh Komitmen Organisasi terhadap Organizational Citizenship Behavior $(O C B)$}

Komitmen organisasi merupakan suatu kondisi yang dirasakan oleh pegawai yang dapat menimbulkan perilaku positif yang kuat terhadap organisasi kerja yang dimilikinya. Komitmen pegawai yang lebih besar akan lebih sering berbicara tentang positif tentang institusi, membantu orang lain, dan jauh melebihi harapan normal dalam pekerjaan mereka. Selain itu, pegawai melakukan pekerjaan berdasarkan kehendak mereka sendiri atau tanpa paksaan. Respons positif dari pegawai tersebut akan memunculkan perilaku $O C B$, dimana perilaku $O C B$ ditunjukkan pegawai dengan membantu rekan kerja secara sukarela agar dapat bekerja lebih efisien dari segi waktu dan tenaga. Hasil penelitian Udayana \& Suwandana (2017) menunjukkan bahwa komitmen organisasi berpengaruh positif dan signifikan terhadap Organizational Citizenship Behavior $(O C B)$ pada Bar and Restaurant Sliperry Stone.

H2: Komitmen organisasi berpengaruh positif dan signifikan terhadap Organizational Citizenship Behavior $(O C B)$ pada pegawai non-PNS di Kementerian Sosial Republik Indonesia.

\section{Pengaruh Job Insecurity terhadap Organizational Citizenship Behavior (OCB)}

Semakin tinggi job insecurity, maka semakin rendah Organizational Citizenship Behavior (OCB). Hal ini sejalan dengan penelitian oleh Greenhalgh \& Rosenblatt (1984) yang menyatakan bahwa job insecurity adalah ketidakberdayaan seseorang atau perasaan kehilangan kekuatan untuk mempertahankan kesinambungan yang diinginkan dalam kondisi/situasi kerja yang terancam. Pentingnya membangun $O C B$ di lingkungan kerja tidak dapat dipisahkan dari bagaimana keamanan kerja dirasakan oleh individu. Tetapi sebaliknya, jika yang terjadi adalah ketidakamanan kerja, kemungkinan menciptakan $O C B$ dalam organisasi akan sulit.

H3: Job insecurity berpengaruh negatif dan signifikan terhadap Organizational Citizenship Behavior $(O C B)$ pada pegawai non-PNS di Kementerian Sosial Republik Indonesia.

\section{METODE PENELITIAN}

Penelitian ini menggunakan pendekatan penelitian kuantitatif. Sugiyono (2015:11) mengemukakan bahwa metode kuantitatif adalah metode penelitian yang berlandaskan pada filsafat positivisme, digunakan untuk meneliti pada populasi atau sampel tertentu, pengumpulan data menggunakan instrumen penelitian, analisis data bersifat kuantitatif/statistik, dengan tujuan untuk menguji hipotesis yang telah ditetapkan.

Populasi dalam penelitian ini adalah 102 pegawai honorer Direktorat Jenderal Perlindungan dan Jaminan Sosial, Kementerian Sosial Republik Indonesia. Sampel dalam penelitian ini adalah 75 pegawai honorer Direktorat Jenderal Perlindungan dan Jaminan Sosial, Kementerian Sosial Republik Indonesia. Penelitian ini menggunakan teknik probability sampling, khususnya simple random sampling. Teknik pengumpulan data dilakukan dengan menggunakan kuesioner.

Analisis data dalam penelitian ini menggunakan metode Partial Least Square (PLS). Langkah-langkah metode Partial Least Square (PLS) yang dilakukan dalam penelitian ini adalah sebagai berikut:

1. Merancang Model Struktural (Inner Model)

2. Merancang Model Pengukuran (OuterModel)

3. Mengkonstruksi Diagram Jalur 
4. Konversi Diagram Jalur ke Sistem Persamaan

5. Estimasi: Koef. Jalur, Loading dan Weight: melalui nilai loading factor, Average Variance Extracted (AVE), dan nilai output Composite Reability (CR).

6. Evaluasi Goodness of Fit: melalui $Q$-square predictive relevance.

7. Pengujian Hipotesis (Resampling Bootstrapping): melalui uji $\mathrm{t}$

\section{HASIL DAN PEMBAHASAN}

\section{Model Pengukuran (Outer Model)}

Langkah pertama yang dilakukan adalah menguji apakah model sudah memenuhi convergent validity, yaitu apakah loading factor indikator untuk masing-masing konstruk sudah memenuhi convergent validity. Hasil uji validitas diagram jalur dengan Smart-PLS 3.0 menunjukkan diagram jalur yang terbentuk adalah seperti Bagan 2 Model Pengukuran (Outer Model).

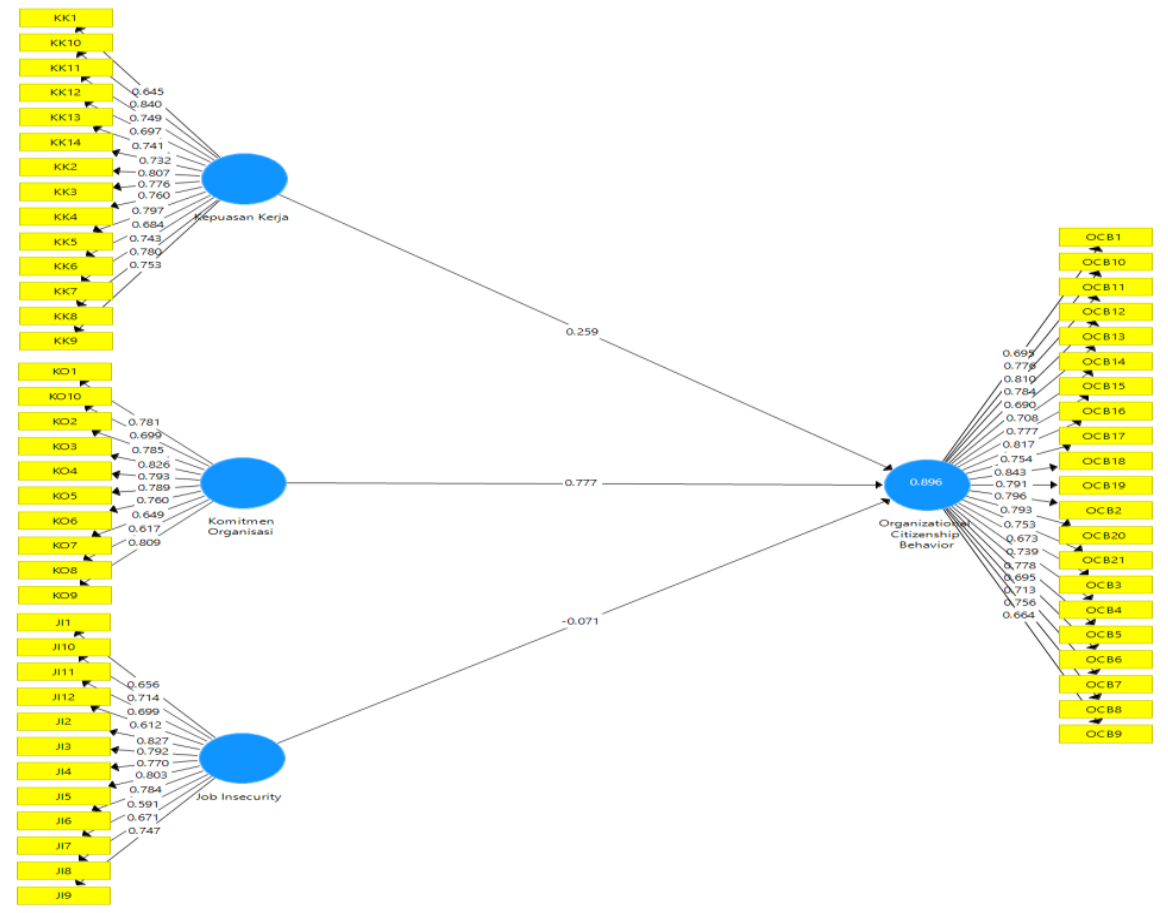

Gambar 1. Model Pengukuran (Outer Model)

Sumber: Hasil Output Smart-PLS, 2019.

Indikator dianggap valid jika memiliki nilai kolerasi di atas 0.70. Namun, pada riset tahap pengembangan, skala loading 0.50 sampai 0.60 masih dapat diterima (Ghozali, 2014:39). Bagan 2 diatas menunjukkan bahwa setiap instrumen pernyataan pada indikator variabel Kepuasan Kerja, Komitmen Organisasional, Job Insecurity, dan Organizational Citizenship Behavior memiliki nilai loading factor $>0.50$. Nilai loading factor $<0.50$ akan dihapus atau dire-estimasi dan tidak diikutsertakan dalam analisis pengajuan data selanjutnya. Variabel Kepuasan Kerja, Komitmen Organisasional, Job Insecurity, dan Organizational Citizenship Behavior memiliki kriteria valid dan tidak ada kendala dalam indikatornya, karena memiliki nilai loading factor $>0.50$. 
Instrumen pernyataan pada indikator yang dipergunakan dalam penelitian ini adalah valid atau telah memenuhi persyaratan uji validitas konvergen (convergent validity). Bagan diatas juga menunjukkan garis yang menghubungkan variabel dependen terhadap variabel independen.

\section{Uji Reliabilitas $P L S$}

Langkah selanjutnya setelah diperoleh validitas dari masing-masing instrumen pertanyaan per-variabel yaitu adalah dilakukannya uji reliabilitas. Uji reliabilitas ini dapat dilihat dari nilai Composite Reliability dan Cronbach's Alpha yang diperoleh dari hasil output software Smart-PLS 3.0. Nilai Composite Reliability dan Cronbach's Alpha penelitian ini dapat dilihat pada Tabel 1 Nilai Composite Reliability dan Cronbach's Alpha.

Tabel 1. Nilai Composite Reliability dan Cronbach's Alpha

\begin{tabular}{|l|c|c|}
\hline \multicolumn{1}{|c|}{ Variabel } & $\begin{array}{c}\text { Composite } \\
\text { Reliability }\end{array}$ & $\begin{array}{c}\text { Cronbach's } \\
\text { Alpha }\end{array}$ \\
\hline Kepuasan Kerja & 0.948 & 0.940 \\
\hline Komitmen Organisasional & 0.929 & 0.914 \\
\hline Job Insecurity & 0.930 & 0.918 \\
\hline Organizational Citizenship Behavior & 0.965 & 0.962 \\
\hline
\end{tabular}

Sumber: Hasil Output Smart-PLS, 2019.

Tabel 1 diatas menunjukkan bahwa nilai composite reliability dan cronbach's alpha untuk semua konstruk adalah $>0.70$. Hal tersebut menunjukkan bahwa semua konstruk pada model yang di estimasi memenuhi kriteria. Variabel kepuasan kerja memiliki nilai composite reliability sebesar 0.948 dan nilai cronbach's alpha sebesar 0.940. Variabel komitmen organisasional memiliki nilai composite reliability sebesar 0.929 dan nilai cronbach's alpha sebesar 0.914. Variabel job insecurity memiliki nilai composite reliability sebesar 0.930 dan nilai cronbach's alpha sebesar 0.918. Variabel organizational citizenship behavior memiliki nilai composite reliability sebesar 0.965 dan nilai cronbach's alpha sebesar 0.962 .

Tabel 1 menunjukkan bahwa semua variabel memiliki reliabilitas yang sangat baik terhadap masing-masing konstruknya serta memenuhi persyaratan sesuai dengan tingkat reliabilitas berdasarkan Nilai Alpha Cronbach. Uji reliabilitas menunjuk pada suatu pengertian bahwa instrumen yang digunakan dalam penelitian untuk memperoleh informasi yang digunakan dapat dipercaya sebagai alat pengumpulan data dan mampu mengungkap informasi yang sebenarnya di lapangan.

\section{R-Square}

Langkah selanjutnya setelah seluruh butir pernyataan per variabel dinyatakan valid, seluruh variabel juga dinyatakan reliabel, maka langkah selanjutnya adalah menguji model struktural penelitian melalui uji $R$ Square. Hasil output software Smart-PLS 3.0 mengenai uji $R$-Square dapat dilihat pada Tabel 2 Hasil Pengukuran Nilai $R$ Square. 
Tabel 2 Hasil Pengukuran Nilai $R$ Square

\begin{tabular}{|c|c|}
\hline & $\boldsymbol{R}$ Square \\
\hline Organizational Citizenship Behavior & 0.896 \\
\hline
\end{tabular}

Sumber: Hasil Output Smart-PLS, 2019.

Tabel 2 diatas menunjukkan bahwa besarnya $R$ Square organizational citizenship behavior adalah sebesar 0.896, yang artinya kepuasan kerja, komitmen organisasional, dan job insecurity berpengaruh terhadap organizational citizenship behavior sebesar $89,6 \%$ dan sisanya $10,4 \%$ dipengaruhi oleh variabel lain seperti gaya kepemimpinan, budaya organisasi, dan loyalitas kerja.

\section{Pengujian Hipotesis}

Setelah butir pernyataan per variabel dinyatakan valid, kemudian seluruh variabel juga dinyatakan reliabel dan model struktural penelitian dinyatakan fit, maka dapat dilanjutkan dengan melakukan uji t-statistik penelitian. Uji t-statistik pada penelitian ini menggunakan uji $\mathrm{t}$ atau uji parsial. Uji t-statistik digunakan untuk mengetahui ada atau tidaknya pengaruh antara kepuasan kerja, komitmen organisasional, dan job insecurity terhadap organizational citizenship behavior.

Sarjono \& Julianita (2011:133) menyatakan bahwa untuk mencari nilai t-tabel dapat dilihat dari taraf signifikansi 0.05 , dan taraf t-tabel yang diperoleh dari $\mathrm{df}=$ jumlah sampel jumlah variabel. Maka diketahui t-tabel $=1.994$ yang diperoleh dari rumus $\mathrm{df}=\mathrm{N}-\mathrm{K}$ atau $\mathrm{df}=$ $75-4=71$, kemudian dihubungkan dengan derajat kesalahan 5\% atau 0.05. Hasil pengolahan data untuk uji signifikansi (Uji t) dapat dilihat pada Tabel 3 Uji t-Statistik.

\section{Tabel 3 Uji t-Statistik}

\begin{tabular}{|l|l|l|l|}
\hline & $\begin{array}{l}\text { Original } \\
\text { Sample }\end{array}$ & $\begin{array}{l}\text { T Statistics } \\
(\mid \mathbf{O} / \text { STDE] }\end{array}$ & $\begin{array}{l}\text { P } \\
\text { Values }\end{array}$ \\
\hline $\begin{array}{l}\text { Kepuasan Kerja -> } \\
\text { Organizational Citizenship Behavior }\end{array}$ & 0.259 & 2.377 & 0.018 \\
\hline $\begin{array}{l}\text { Komitmen Organisasional -> Organizational } \\
\text { Citizenship Behavior }\end{array}$ & 0.777 & 8.977 & 0.000 \\
\hline $\begin{array}{l}\text { Job Insecurity -> } \\
\text { Organizational Citizenship Behavior }\end{array}$ & -0.071 & 0.620 & 0.536 \\
\hline
\end{tabular}

Sumber: Hasil Output Smart-PLS, 2019.

\section{Pengujian Hipotesis 1}

Pengujian hipotesis 1 untuk membuktikan bahwa Kepuasan Kerja memiliki pengaruh yang signifikan terhadap Organizational Citizenship Behavior $(O C B)$ pada pegawai non-PNS di Kementerian Sosial Republik Indonesia. Hipotesis alternative disusun sebagai berikut:

Ha1: Kepuasan kerja berpengaruh positif dan signifikan terhadap Organizational Citizenship Behavior $(O C B)$ pada pegawai non-PNS di Kementerian Sosial Republik Indonesia.

Ho1: Kepuasan kerja tidak berpengaruh positif dan signifikan terhadap Organizational Citizenship Behavior (OCB) pada pegawai non-PNS di Kementerian Sosial Republik Indonesia. 
Berdasarkan hasil pengujian pada tabel 3, dapat dilihat bahwa hasil pengujian variabel Kepuasan Kerja terhadap Organizational Citizenship Behavior (OCB) menunjukan nilai thitung $2.377>$ t-tabel 1.994 dan P-value sebesar $0.018<0.05$ ini menunjukan bahwa Kepuasan Kerja berpengaruh signifikan terhadap Organizational Citizenship Behavior (OCB). Hal tersebut menunjukkan bahwa semakin meningkat Kepuasan Kerja maka Organizational Citizenship Behavior (OCB) semakin meningkat pula atau kearah lebih baik. Adapun pengaruh positif antara Kepuasan Kerja terhadap Organizational Citizenship Behavior (OCB) dapat dilihat dari nilai Original Sample sebesar 0.259. Berdasarkan t-hitung yang lebih besar dari penelitian ini, maka disimpulkan bahwa Ha1 diterima dan Ho1 ditolak.

\section{Pengujian Hipotesis 2}

Pengujian hipotesis 2 untuk membuktikan bahwa Komitmen Organisasional memiliki pengaruh yang signifikan terhadap Organizational Citizenship Behavior (OCB) pada pegawai non-PNS di Kementerian Sosial Republik Indonesia. Hipotesis alternative disusun sebagai berikut:

Ha2: Komitmen organisasional berpengaruh positif dan signifikan terhadap Organizational Citizenship Behavior (OCB) pada pegawai non-PNS di Kementerian Sosial Republik Indonesia.

Ho2: Komitmen organisasional tidak berpengaruh positif dan signifikan terhadap Organizational Citizenship Behavior (OCB) pada pegawai non-PNS di Kementerian Sosial Republik Indonesia.

Berdasarkan hasil pengujian pada tabel 3, dapat dilihat bahwa hasil pengujian variabel Komitmen Organisasional terhadap Organizational Citizenship Behavior (OCB) menunjukan nilai t-hitung $8.977>$ t-tabel 1.994 dan P-value sebesar $0.000<0.05$ ini menunjukan bahwa Komitmen Organisasional berpengaruh signifikan terhadap Organizational Citizenship Behavior $(O C B)$. Hal tersebut menunjukkan bahwa semakin meningkat Komitmen Organisasional maka Organizational Citizenship Behavior (OCB) semakin meningkat pula atau kearah lebih baik. Adapun pengaruh positif antara Komitmen Organisasional terhadap Organizational Citizenship Behavior $(O C B)$ dapat dilihat dari nilai Original Sample sebesar 0.777. Berdasarkan t-hitung yang lebih besar dari penelitian ini, maka disimpulkan bahwa Ha2 diterima dan Ho2 ditolak.

\section{Pengujian Hipotesis 3}

Pengujian hipotesis 3 untuk membuktikan bahwa Job Insecurity memiliki pengaruh yang signifikan terhadap Organizational Citizenship Behavior (OCB) pada pegawai non-PNS di Kementerian Sosial Republik Indonesia. Hipotesis alternative disusun sebagai berikut:

Ha3: Job insecurity berpengaruh negatif dan signifikan terhadap Organizational Citizenship Behavior $(O C B)$ pada pegawai non-PNS di Kementerian Sosial Republik Indonesia.

Ho3: Job insecurity tidak berpengaruh negatif dan signifikan terhadap Organizational Citizenship Behavior (OCB) pada pegawai non-PNS di Kementerian Sosial Republik Indonesia.

Berdasarkan hasil pengujian pada tabel 3, dapat dilihat bahwa hasil pengujian variabel Job Insecurity terhadap Organizational Citizenship Behavior (OCB) menunjukan nilai t-hitung 0.620 < t-tabel 1.994 dan P-value sebesar $0.536>0.05$ ini menunjukan bahwa Job Insecurity tidak berpengaruh signifikan terhadap Organizational Citizenship Behavior (OCB). Hal 
tersebut menunjukkan bahwa semakin menurun Job Insecurity maka Organizational Citizenship Behavior (OCB) semakin menurun pula. Adapun pengaruh negatif antara Job Insecurity terhadap Organizational Citizenship Behavior (OCB) dapat dilihat dari nilai Original Sample sebesar -0.071. Berdasarkan t-hitung yang lebih kecil dari penelitian ini, maka disimpulkan bahwa $\mathrm{Ha}$ ditolak dan $\mathrm{Hoz}$ diterima.

\section{KESIMPULAN DAN SARAN}

Berdasarkan analisis data dan pembahasan yang telah dilakukan mengenai Pengaruh Kepuasan Kerja, Komitmen Organisasional, dan Job Insecurity terhadap Organizational Citizenship Behaviour (OCB) (Studi pada Pegawai Non-PNS Kementerian Sosial RI) maka dapat disimpulkan bahwa Kepuasan Kerja menunjukkan pengaruh yang signifikan terhadap Organizational Citizenship Behavior (OCB), Komitmen Organisasional menunjukkan pengaruh yang signifikan terhadap Organizational Citizenship Behavior (OCB), Job Insecurity menunjukkan pengaruh yang tidak signifikan Organizational Citizenship Behavior (OCB)

\section{DAFTAR RUJUKAN}

\section{Buku:}

Ghozali, Imam. (2014). Structural Equation Modelling, Metode Alternatif dengan Partial Least Square (PLS): Edisi 4. Semarang: BPFE Universitas Diponegoro.

Hellriegel, D dan Slocum, J. W. (2011). Organizational Behavior. Mason: South Western, Cengage Learning.

Ivancevich, J. M. et al. (2011). Perilaku \& Manajemen Organisasi. Jakarta: Erlangga.

Kreitner, Robert dan Kinicki, Angelo. (2014). Perilaku Organisasi: Edisi 9, Buku ke-2. Jakarta: Salemba Empat.

Luthans, F. (2012). Perilaku Organisasi. Yogyakarta: ANDI.

Noe, Raymond A., Hollenbeck, John R., Gerhart, Barry., dan Wright, Patrick M. (2014). Manajemen Sumber Daya Manusia: Mencapai Keunggulan Bersaing: Edisi 6, Jilid 2. Jakarta: Salemba Empat.

Robbins, Stephen P., and Judge, Timothy A. (2013). Organizational Behavior Edition 15. New Jersey: Pearson Education.

Sarjono, H. dan Julianita, W. (2013). SPSS VS LISREL: Sebuah Pengantar, Aplikasi untuk Riset. Jakarta: Salemba Empat.

Sinambela, Lijan Poltak. (2016). Manajemen Sumber Daya Manusia. Jakarta: PT. Bumi Aksara.

Sopiah. (2011). Perilaku Organisasi. Yogyakarta: Andi Offset.

Sugiyono. (2015). Metode Penelitian Kuantitatif, Kualitatif dan R\&D. Bandung: Alfabeta.

Titisari, Purnamie. (2014). Peranan Organizational Citizenship Behavior (OCB) dalam Meningkatkan Kinerja Karyawan. Jakarta: Mitra Wacana Media.

\section{Publikasi Ilmiah:}

Bateman, Thomas S. and Organ, Dennis W. (1983). Job Satisfaction and the Good Soldier: the Relationship Between Affect and Employee "Citizenship". the Academy ff Management Journal vol. 26 No. 4.

Brahmasari, I. A. (2008). Pengaruh Variabel Budaya Organisasi, Komitmen dan Kepuasan Kerja Pegawai terhadap Organizational Citizenship Behavior Pegawai. Jurnal Akuntansi, Manajemen Bisnis dan Sektor Publik (JAMBSP). 4 (3) : 269-290.

Budiharjo. (2004). Mengenal Organizational Citizenship Behavior (OCB). Forum Manajemen Prasetiya Mulya Tahun ke-XVIII, No. 82. 
Darto, Mariman. (2014). Peran Organizational Citizenship Behavior (OCB) dalam Peningkatan Kinerja Individu di Sektor Publik: Sebuah Analisis Teoritis dan Empiris. Jurnal Borneo Administrator, vol. 10 No. 1.

De Witte, H. (2005). Job Insecurity: Review of the International Literature on Definitions, Prevalence, Antecedents and Consequences. Journal of Industrial Psychology, 31, 1-6.

Greenglass, Esther, Ronald Burke and Lisa Fiksenbaum. (2002). Impact of Restructuring, Job Insecurity and Job Satisfaction in Hospital Nurses. Sress News January, 14(1) : 1-10.

Greenhalgh, L. and Rosenblatt, Z. (1984). Job Insecurity: Toward Conceptual Clarity. Academy of Management Review $3: 438-488$.

Lubis, M. S. (2015). Pengaruh Iklim Organisasi dan Komitmen Organisasi terhadap Pembentukan Organizational Citizenship Behavior (OCB) Karyawan. e-Jurnal Apresiasi Ekonomi. 3 (2) : 75-84.

Organ, D. W. and Konovsky, M. A. (1989). Cognitive Versus Affective Determinants of Organizational Citizenship Behavior. Journal of Applied Psychology, 74 : 157-164.

Shah, S. M. A. et al. (2012). the Impact of Employee Job Satisfaction on the Organizational Commitment: a Study of Faculty Members of Public Sector Universities of Pakistan. Interdisciplinary Journal of Contemporary Research in Business, 3 (10) : 161-170.

Smithson, J. and Lewis, S. (2000). is Job Insecurity Changing the Psychological Contract?. Personnel Review, 29 (6) : 1-15.

Stynen, D., Forrier, A., Sels, L. and De Witte, H. (2015). the Relationship Between Qualitative Job Insecurity and OCB: Differences Across Age Groups. Economic and Industrial Democracy, 36 (3) : 383-405.

Sudarmo, Thessa Imay dan Wibowo, Ugung Dwi Ario. (2018). Pengaruh Komitmen Organisasional dan Kepuasan Kerja terhadap Organizational Citizenship Behavior (OCB). PSYCHO IDEA, Tahun 16 No. 1, Februari 2018 ISSN : 1693-1076.

Udayana, I Putu Gede Paramita dan Suwandana, I Gusti Made. (2017). Pengaruh Kepuasan Kerja dan Komitmen Organisasional terhadap Organizational Citizenship Behavior. EJurnal Manajemen, [S.L.], Vol. 6, No. 7 : 3570 - 3594, ISSN : 2302-8912.

Publikasi Instansi:

Badan Nasional Penanggulangan Bencana. Potensi dan Ancaman Bencana. https://bnpb.go.id//potensi-bencana. Diakses pada 27 Maret 2019, pukul 19:57. 